\title{
Comparative Study of Indonesian Seismic Codes Applied on Vertically Irregular RC Building in High Seismicity Region
}

\author{
Muhammad Ibnu Syamsi ${ }^{\mathbf{*}}$, Taufiq Ilham Maulana ${ }^{\mathbf{1}}$, Hararya Widyantama ${ }^{\mathbf{1}}$, \\ Muhammad Rezki Ian ${ }^{1}$, Redi Indra Lesmana ${ }^{1}$
}

${ }^{1}$ Department of Civil Engineering,

Universitas Muhammadiyah Yogyakarta, Kasihan, Bantul, 55183, INDONESIA

*Corresponding Author

DOI: https://doi.org/10.30880/ijie.2021.13.03.019

Received 20 December 2020; Accepted 01 May 2021; Available online 06 June 2021

\begin{abstract}
The Aceh earthquake suffering Indonesia in 2004, and some big ground motions afterward led the earthquake-resistant building standard provisions to be updated. The rise of ground motions increases the lateral forces, so reevaluating existing buildings is needed, especially for Irregular buildings, which are more vulnerable than the regular ones. This study investigates the increase of earthquake loads and the building response in the high seismicity region due to the updated Indonesian code from SNI 1726:2002 to SNI 1726:2012. Building A in DI Yogyakarta with vertical irregularity on a certain floor is chosen as the object to be studied. There are two types of seismic loads to be simulated, response spectrum and time history analysis. The building is simulated using the numerical program, and four ground motion histories are selected for the dynamic exiting forces. The analysis result shows an increase in the story force either in the response spectrum or the time history. By taking the building's top floor as the reference point, the increase in lateral displacement is also detected in both response spectrum and time history analysis. From the interstory drift ratio examinations, it is also found that there is a weak point located on the setback part that is not identified just by observing the total displacement. This paper compiles the comparison of two versions of the Indonesian seismic code, two types of seismic force, and two points of view in analyzing the building response. Furthermore, the result presented in this paper also beneficial for mitigating the building.
\end{abstract}

Keywords: Vertical irregularity, setback, response spectrum, time history, interstory drift

\section{Introduction}

Most of Indonesia is earthquake hazard areas due to its location surrounded by three active tectonic plates. From 1991 to 2009, about 30 destructive earthquakes and 14 destructive tsunamis have been recorded, e.g., Nias Earthquake in 2005, West Java was in 2006, Bengkulu was in 2007. Besides, some earthquakes followed by tsunamis, such as on December $12^{\text {nd }} 1991$, the Flores tsunami had claimed more than 2000 people. It is followed by the East Java tsunami in 1994, the Biak tsunami in 1996, the Sulawesi tsunami in 1998, the North Maluku tsunami in 2000, and the Aceh tsunami in 2004. Those earthquakes caused many casualties and fatal damage to the building with various collapse patterns, so the safety of building in seismic zone must be considered, especially for multistory buildings [1]. Many factors need to be considered in designing the building, and the security aspect is the main, especially for multistory buildings [2]. The same consideration also must be applied to an existing building. One effort to reduce the impact of the earthquake disaster is by identifying and evaluating the existing building response under the threat of an earthquake, especially for buildings with irregularity either vertically or horizontally, which have larger vulnerability compare to 
the regular one [2]-[4]. Therefore, if there are any potential damages in the building, an anticipation step can be taken. Mazza reported that a setback building strengthened with damped braces can provide better performance under seismic loads [5].

Building A building located in the DI Yogyakarta was built in 1995 and inaugurated in 1998. The building was built before the Indonesian standard code for the building planning against the earthquake was made, both SNI 1726:2002 [6] and SNI 1726:2012 [7]. The rise of design spectra acceleration in several cities in Indonesia, Yogyakarta, makes the existing building needs more attention to be assessed, especially for important facilities [8]. One of the distinguishing parts of this building is the existence of vertical irregularity. Irregularity building is usually built for aesthetic purposes. Discontinuity of mass, stiffness, and strength in the vertical direction are all regarded as vertical irregularities [9, 10]. Its existence has a significant influence on the behavior of the building response [11]. Stress concentration is greater around the irregular members and can trigger structural damage [12]. In the plan view, the building is near looks like a square shape, but in a certain level of story, the building shape is diagonally plan-sliced, resulting in the sudden change of the building's mass and stiffness. This condition is commonly regarded as a setback. It is a condition when there is a sudden change in the number of bays between the building story. The bottom part, which consists of many bays, is called the base, while the upper part for the fewer bays is regarded as the tower [9]. Besides, this building is located in Yogyakarta with a high seismicity category. When the structures are located in the high seismicity zone, the engineer must have a much better understanding of the irregular building response under the earthquake load [9]. The seismic response in vertically irregular buildings can be seriously distinct compared to the regular one [13].

Some investigations about the buildings' irregularity effect have been performed [3], [4], [10]-[12], [14]. The seismic effect on vertically irregular building structures is well-reviewed by Soni \& Mistry [14]. The seismic performance of multistory RC setback buildings subjected to pushover and time history analysis using Eurocode is presented by Athanassiadou [3]. Meanwhile, RC frame building response due to the mass irregularity in elevation performed and discussed by Sameer \& Shinde [4]. They study the drift, deflection, and shear force of each story subjected to static and dynamic seismic loads. Five 50-story buildings in medium seismicity are designed with different vertical irregularity features by Mwafy \& Khalifa [10] to assess the international building codes through many pushovers and dynamic analysis [10]. The analytical study for the variation effect of stiffness change vertically to the maximum interstory drift ratio on the existing RC building using the Uniform Building Code (UBC) is reported by Shahrooz \& Moehle [11]. The observations are supplemented by experimental work on a $50 \%$ setback building in the mid-height with a one-quarter scale model and performed uses a shaking table. Some case studies for varied configurations of irregular structures are performed using response spectral and nonlinear time history analysis by Dutta et al. [12]. They emphasize that higher ductility demand appeared nearby the irregularity. Other investigations on vertical irregularities take concern in SMF for steel building [13], [15]. Le-Trung [13] presented the evaluation of several irregular buildings subjected to 20 earthquakes with an exceedance probability of 50 years using IBC 2000 provisions. Dynamical behavior of multistory steel rigid frame buildings with setback towers subjected to El-Centro ground motion are studied by Humar \& Wright [15]. Muljati \& Lumantarna [16] have studied the previous study using the Indonesian seismic code of the year 2002 (SNI 1726:2002) to evaluate the seismic performance Vertical irregularity performance. The analysis is conducted through time history analysis for 10 -story buildings with $50 \%$ vertically irregularity.

The research related to vertical irregularity attracts many researchers to understand better this type of building [4], [11], [13], [15], [16]. However, the comparison of setback building response due to the rise of earthquake intensity in high seismicity regions has not been conducted. The importance of building evaluation in Indonesia is supported by Indonesia's earthquake frequency, especially after the huge scale of ground motion in Aceh in 2004. As the impact of updating the Indonesian standard for earthquake resistant building from 2002 to 2012, the structural behavior will differ [2]. Therefore, this study aims to find out the rise of earthquake load and building response according to the Indonesian seismic code of 2002 and 2012 to provide information as a mitigating plan for such a case of presented building. The earthquake analysis simulated includes response spectra and time history analysis. These two input parameters are used to evaluate their effect on the structure behavior, deformation, earthquake forces, and the interstory drift ratio in the seismic hazard area. Interstory drift ratio, which is defined as the ratio between the relative displacement of two sequential floors to their associated height, is commonly chosen as the parameters in some methodologies to analyze the losses due to the earthquake [17], [18]. Moreover, checking the maximum interstory drift ratio of buildings to the threshold limit is required in the modern codes [19], [20].

\section{Research Method}

Generally, this research consists of preparation, data collection, structure analysis, and result comparison step. First of all, building data collection and confirmation is essential. If there are different data, the real data is preferred. Structure analysis is conducted in three dimensions using the numerical program based on the updated data. Two versions of Indonesian codes are adopted and compared in these analyses are SNI 1726:2002 and SNI 1726:2012. For more convenience in the further discussion, SNI 1726:2002 will be denoted as SNI2002, whereas SNI 1726:2012 is named as SNI2012. 
The earthquake load to be examined are mainly the response spectra and time history. Before outputting the result of structural response due to seismic load, both earthquake loads must be checked first; their shear force is $85 \%$ minimal from the first mode's seismic base shear. The structural analysis, base shear, displacement, and the drift ratio are compared to obtain each output relation. The base shear and displacement analysis method is also written in FEMA451 [21]. Interstory drift ratio is obtained by dividing the magnified story drift $\left(\Delta_{\mathrm{x}}\right)$, which is obtained from relative elastic displacement $\left(\delta_{e x}\right)$ of two sequential floors to the associated height. Besides, the deflection magnification factor $\left(C_{d}\right)$ and building importance factor $\left(I_{e}\right)$ must be included in determining the $\Delta_{\mathrm{x}}$, as shown in Eq. (1). All coefficient used is provided in Indonesian seismic code, including the allowable story drift $\left(\Delta_{\mathrm{a}}\right)$.

$$
\Delta_{x}=\frac{C_{d}\left(\delta_{e x}-\delta_{e(x-1)}\right)}{I_{e}} \leq \Delta_{a}
$$

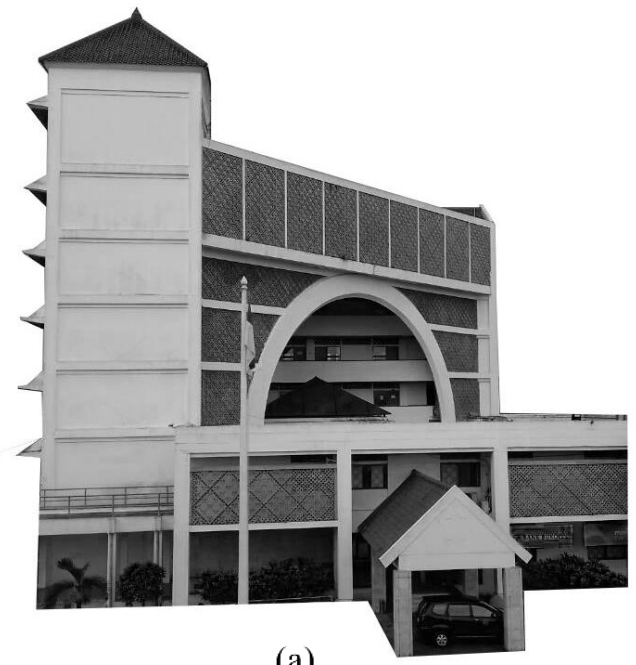

(a)

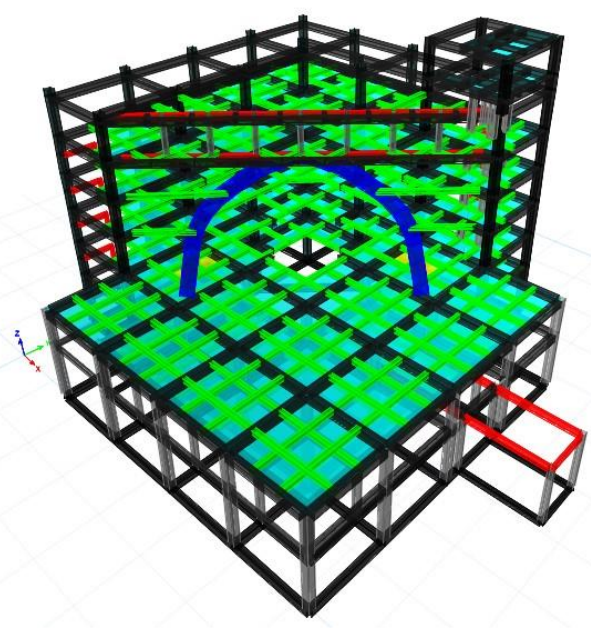

(b)

Fig. 1 - 3D building model of the observed building (a) Building A; (b) 3D model of Building A

The main component of this building is reinforced concrete and categorized as the moment-resisting frame structure system. This seven floors building is located in DI Yogyakarta Province with high seismicity and moderate soil type. The building's vertical irregularity can be observed in the numerical model, as shown in Fig. 1. Ground, $1^{\text {st }}$, and $2^{\text {nd }}$ floor have quite the same area. Meanwhile, the area of the $3^{\text {rd }}$ up to the $7^{\text {th }}$ floor has approximately half of the first three floors. This condition triggers a significant rise in story drifts value, which will affect the building became unsafe due to the latest earthquake condition. The roof structure is separately analyzed to simplify the structure modeling, and the reactions of roof trusses are loaded on the building frame structure.

This building is classified in risk category IV with the $I_{e}$ value of 1.5. Although it is an office building with the risk category II, there are educational facilities and seminar rooms or public lectures on several floors. Thus, to accommodate all of those floors, the risk category with the worse assumption or category IV is decided. The limit state of interstory drift is also essential to be determined as the threshold of building response. The building is labeled as safe if the story drifts or the displacements do not exceed the allowable limit $\left(\Delta_{a}\right)$. According to the SNI2012, the limit of interstory drift for the building with the type of moment-resisting frame structure without shear wall with risk category IV is $1 \%$ (see Table 1 ).

\section{Seismic Loads}

Based on the SNI2002, Yogyakarta as the targetted building location is categorized in earthquake zone 3 with the peak ground acceleration value of $0.15 \mathrm{~g}$. Since the soil type on the building location is moderate soil, the response spectra parameters $\mathrm{A}_{0}, \mathrm{~A}_{\mathrm{m}}$, and $\mathrm{A}_{\mathrm{r}}$ are $0.22,0.55$, and 0.33 . Meanwhile, in the SNI2012, the desired location's response spectrum parameters, $\mathrm{S}_{\mathrm{s}}, \mathrm{S}_{1}, \mathrm{~F}_{\mathrm{a}}$, and $\mathrm{F}_{\mathrm{v}}$ are 1.04, 0.396, 1.084, and 1.608, respectively. According to the above parameters, the response spectra for each version of the Indonesian code (SNI2002 and SNI2012) are constructed and can be observed in Fig. 2. Since the response spectrum applied to the building must be adjusted to the base shear of the first mode; thus, Equivalent lateral force (ELF) is necessary to be calculated. The amount of the equivalent static earthquake load based on SNI2002 and SNI2012 are shown in Table 2. 
Table 1 - Allowable interstory drift [7]

\begin{tabular}{lccc}
\hline Structure & \multicolumn{2}{c}{ Risk category } \\
III & I or II & IV \\
\hline $\begin{array}{l}\text { Structure, except the masonry shear wall, 4 level or less with the } \\
\text { interior wall, partition, ceiling, and exterior wall system }\end{array}$ & $0.025 \mathrm{~h}_{\mathrm{sx}}$ & $0.020 \mathrm{~h}_{\mathrm{sx}}$ & $0.015 \mathrm{~h}_{\mathrm{sx}}$ \\
$\begin{array}{l}\text { designed to accommodate floor level deformation. } \\
\text { Cantilever masonry shear wall structure }\end{array}$ & $0.010 \mathrm{~h}_{\mathrm{sx}}$ & $0.010 \mathrm{~h}_{\mathrm{sx}}$ & $0.010 \mathrm{~h}_{\mathrm{sx}}$ \\
Other masonry shear wall structure & $0.007 \mathrm{~h}_{\mathrm{sx}}$ & $0.007 \mathrm{~h}_{\mathrm{sx}}$ & $0.007 \mathrm{~h}_{\mathrm{sx}}$ \\
Other structures & $0.020 \mathrm{~h}_{\mathrm{sx}}$ & $0.015 \mathrm{~h}_{\mathrm{sx}}$ & $0.010 \mathrm{~h}_{\mathrm{sx}}$ \\
\hline
\end{tabular}

$\mathrm{h}_{\mathrm{sx}}$ : story height below the $\mathrm{x}^{\text {th }}$ floor

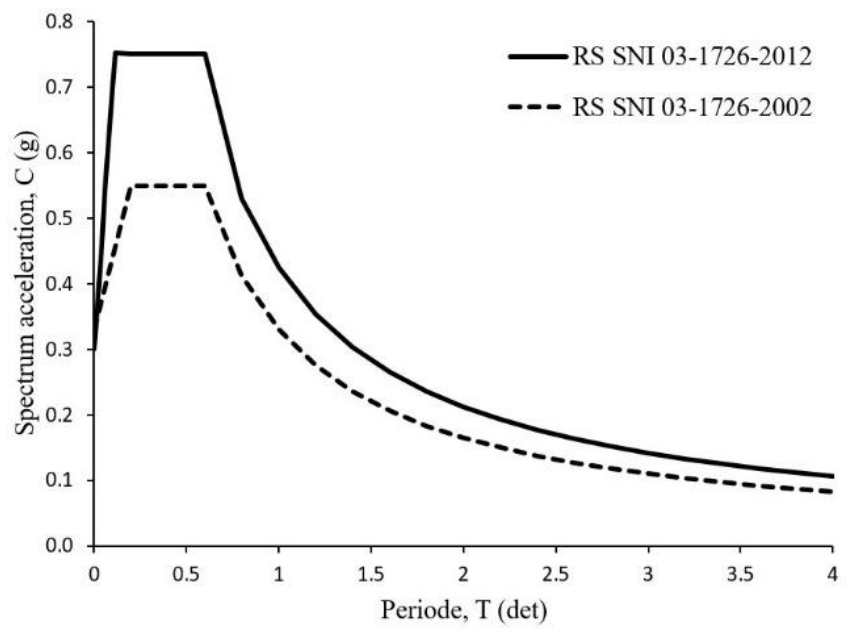

Fig. 2 - Comparison of design earthquake response spectrum based on SNI2002 and SNI2012

Table 1 - Allowable interstory drift [7]

\begin{tabular}{ccccc}
\hline Floor & $\mathbf{h}_{\mathbf{x}}(\mathbf{m})$ & $\mathbf{W}_{\mathbf{x}}(\mathbf{k N})$ & $\mathbf{f}_{\mathbf{x}}(\mathbf{S N I 2 0 0 2})$ & $\mathbf{f}_{\mathbf{x}}(\mathbf{S N I 2 0 1 2})$ \\
\hline Roof & 24.70 & 366.41 & 35.83 & 151.95 \\
6 & 21.28 & 1334.18 & 112.39 & 461.18 \\
5 & 17.86 & 6040.13 & 427.06 & 1685.52 \\
4 & 14.40 & 4602.85 & 262.39 & 987.31 \\
3 & 11.02 & 4602.85 & 200.80 & 712.04 \\
2 & 7.60 & 9327.06 & 280.62 & 916.35 \\
1 & 4.18 & 9679.96 & 160.18 & 458.10 \\
\hline \multicolumn{5}{c}{ Total } \\
\hline
\end{tabular}

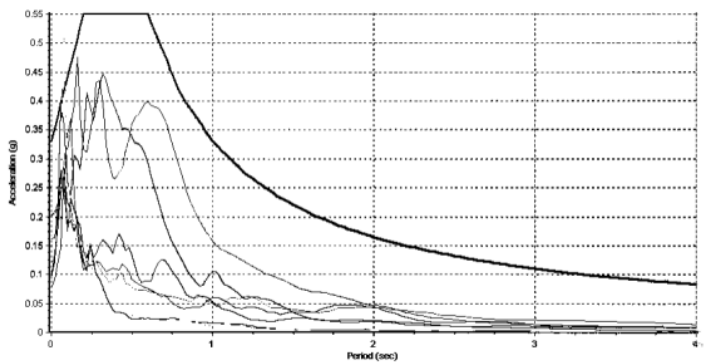

(a)

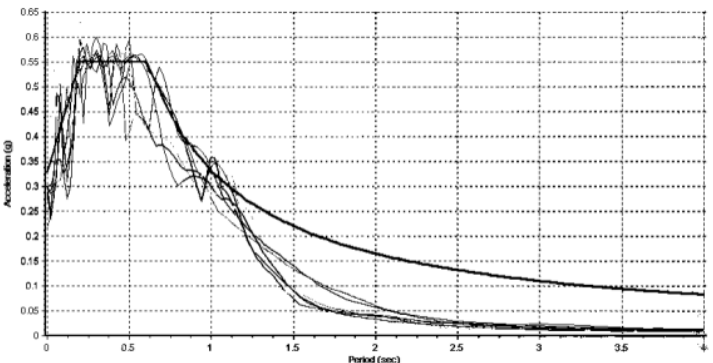

(b)

Fig. 3 - Response spectra of time history records according to SNI2002 (a) before adjusted; (b) after adjusted 


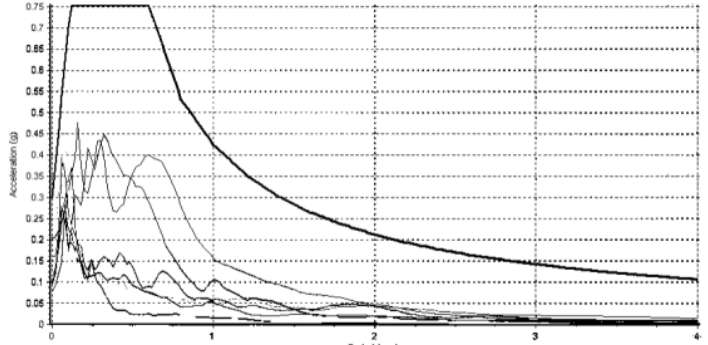

(a)

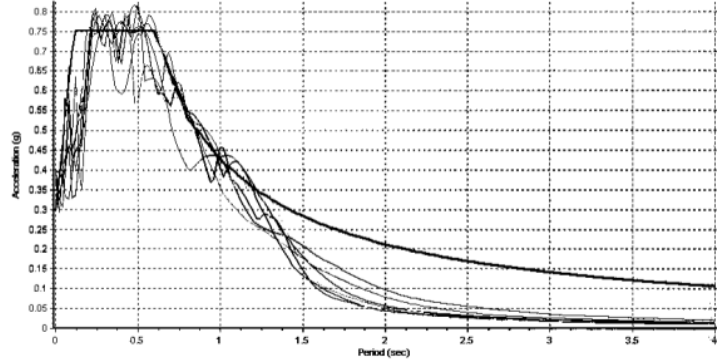

(b)

Fig. 4 - Response spectra of time history records according to SNI2012 (a) before adjusted; (b) after adjusted

On the other side, time history analysis is also studied in this research. Since the original earthquake history record of the location is not available, four earthquake records with the same characteristics are required. These earthquake history records are then obtained from Pacific Earthquake Engineering Research (PEER) Center database by adjusting some parameters related to the earthquake characteristic near the location to be analyzed (such as the fault type, distance to the epicenter, depth, soil type, Ritcher's magnitude scale). Finally, Imperial Valley (IV), Northern California (NC), Morgan Hill (MH), and Superstition Hills ( $\mathrm{SH})$ are chosen as the time history record used in this analysis.

These acceleration histories cannot be directly applied to the targeted building, but it must be modified first according to the design response spectra with the related seismic design code 2002 and 2012. This modification is regulated to adjust the acceleration history to the target location. The adjusted spectral history can be seen in Fig. 3 and Fig. 4. The ground motion must be scaled so that the mean of response spectra with the $5 \%$ attenuation of all appropriate ground motion at the site should be no less than design response spectra for the period 0.2T to 1.5T [7]. The T represents the structure natural vibration period in the fundamental vibration.

\section{Shear Forces}

Based on the seismic provisions of SNI2002, the base shear of the structure is proportional to the weight ( $\left.W_{t}\right)$ earthquake response factor, $C_{l}$, the building importance factor, $I$, and reverse proportion to the reduction factor $(R)$. In other words, it could be said that the base shear is the result of total weight multiplied by a coefficient, as seen in Eq. (2). A similar concept was adopted in SNI2012, as shown in Eq. (3), but the coefficient $\left(C_{s}\right)$ in this version consists of more parameters. Besides, in SNI2012 also consider the fundamental period of the building. The detailed calculation of base shear can be observed in the related Indonesian codes.

$$
\begin{gathered}
V=\left(\frac{C_{1} I}{R}\right) W_{t} \\
V=C_{s} W_{t}
\end{gathered}
$$

Based on these relationships, it is agreed that the magnitude of the seismic loads depends on the total weight of the building [22]. The return period on the earthquake map used by SNI2012 is about 2500 years. This value is bigger than what is used in SNI2002, which is 500 years. The greater the return period used, the bigger the earthquake energy released, so the earthquake force itself is surely bigger. Arfiadi and Satyarno [8] said that the rise of the spectral response value on the short period $\left(\mathrm{S}_{\mathrm{DS}}\right)$ for moderate soil in Yogyakarta increase 1.5 times larger than in Indonesian Seismic Code 2002, whereas the spectral response for one second period ( $\left.\mathrm{S}_{\mathrm{D} 1}\right)$, has increased by 1.4 times than those obtained from SNI2002. A significant increase in the above discussion is agreed with the shear analysis result, as shown in Table 2. The average increase of story shear obtained from the equivalent lateral force (ELF) in SNI2012 is 3.6 times larger than those obtained from SNI2002. The shear force increase is directly proportional to the increase of the peak ground acceleration, which in the SNI2002 is $0.23 \mathrm{~g}$ and in the SNI2012 is $0.462 \mathrm{~g}$. The rise of building story force under the response spectrum can be observed in Fig. 5. The mean of story force increment from SNI2002 to SNI2012 is about 3,9 times. The value between static and response spectrum acceleration is slightly different because the total static force controls the response spectrum's base shear.

On the other side, the story force simulated by four history records, which are Imperial Valley (IV), Northern California (NC), Morgan Hill (MH), and Superstition Hills (SH), has also increased (Fig. 6). All of the acceleration records are simulated for both SNI2002 and SNI2012 in both directions, $\mathrm{x}$ and $\mathrm{y}$. The biggest story force in $\mathrm{x}$-direction based on Indonesian seismic code SNI2012 is obtained from Morgan Hills (2012 MH-X). The y-direction based on the SNI2012 seismic load also occurs from Morgan Hills's time history record (2012 MH-Y). The increase of seismic force 
from SNI2002 to SNI2012 for Morgan Hills time history record on the x and y-direction is respectively 4.82 and 3.86 times larger.

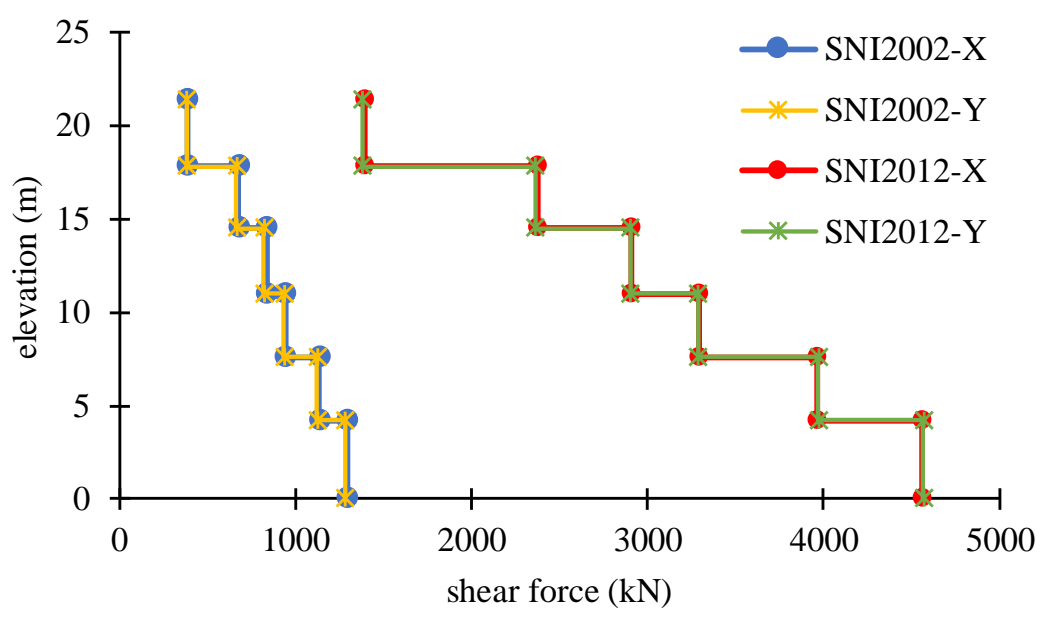

Fig. 5 - The story shear using the response spectrum based on SNI2002 and SNI2012

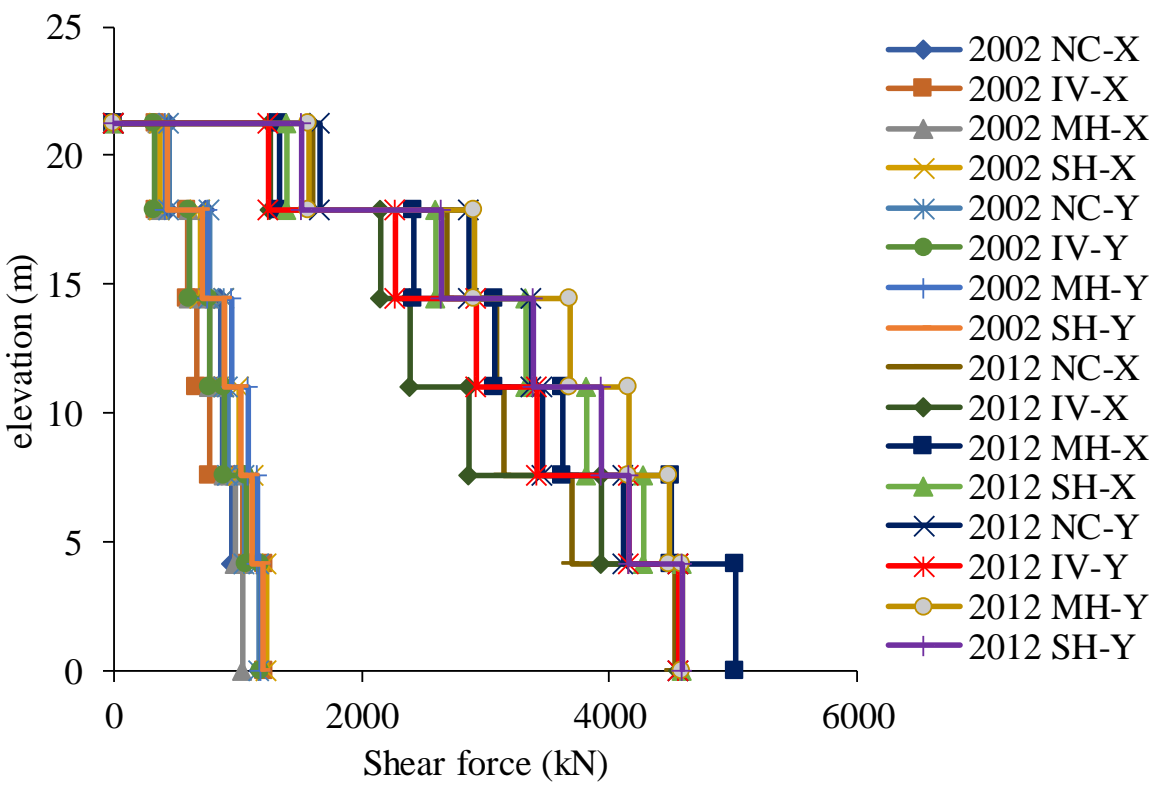

Fig. 6 - The comparison of base shear using time history method based on SNI2002 and SNI2012

\section{Displacement and Interstory Drifts}

The rise of the earthquake return period surely affects earthquake force and affects another structure response, such as building horizontal displacement. The comparison of the horizontal displacement using the response spectrum of SNI2002 and SNI2012 is shown in Fig. 7. It is shown in the figure that the cumulative displacement obtained according to SNI2012 has increased. By taking the displacement on the top floor as the reference, it is obtained that in SNI2012, the displacement increase about 2.2 times larger than SNI2002. And this is agreed with the theory that the displacement is directly proportional to the force value, whereas the force proportional to the acceleration, i.e., the ground motion. The figure also depicts that in SNI2002, the displacement for the $3^{\text {rd }}, 4^{\text {th }}$, and $5^{\text {th }}$ floor are slightly below the limit, while in SNI2012, they are all far enough to the limit. Thus, based on the displacement result, it is stated that each floor all remains safe because the recorded translation is all still lower than the limit either for SNI2002 and SNI2012. Furthermore, it can also be concluded that SNI2002 provides a more conservative result for the design purpose than SNI2012 associated with their earthquake condition.

A similar result is shown in the horizontal displacement response of Building A subjected to the time history force. The same pattern is depicted for both analyses use the SNI2002 and SNI2012; as seen in Fig. 8, the increase of displacement response also appeared in the time history analysis. The result is in line with the modification of the acceleration record in the previous section. The response spectrum target for SNI2012 is greater than SNI2002, and these adjustments affect the magnitude of the acceleration records then lead them to produce a bigger response in 
building displacements. The mean of increase through time history analysis is nearly three times between SNI2002 to SNI2012. Even though the increase of displacement varies between one ground motion to others but the maximum of total displacement for all floors is still in the safe zone, i.e. no displacements exceed the allowable limit for both versions of Indonesian seismic codes. The biggest horizontal displacement is produced from the Superstition Hills ( $\mathrm{SH}$ ) seismic record on the top floor is $58.81 \mathrm{~mm}$, according to SNI2002 and $174.16 \mathrm{~mm}$ for SNI2012.

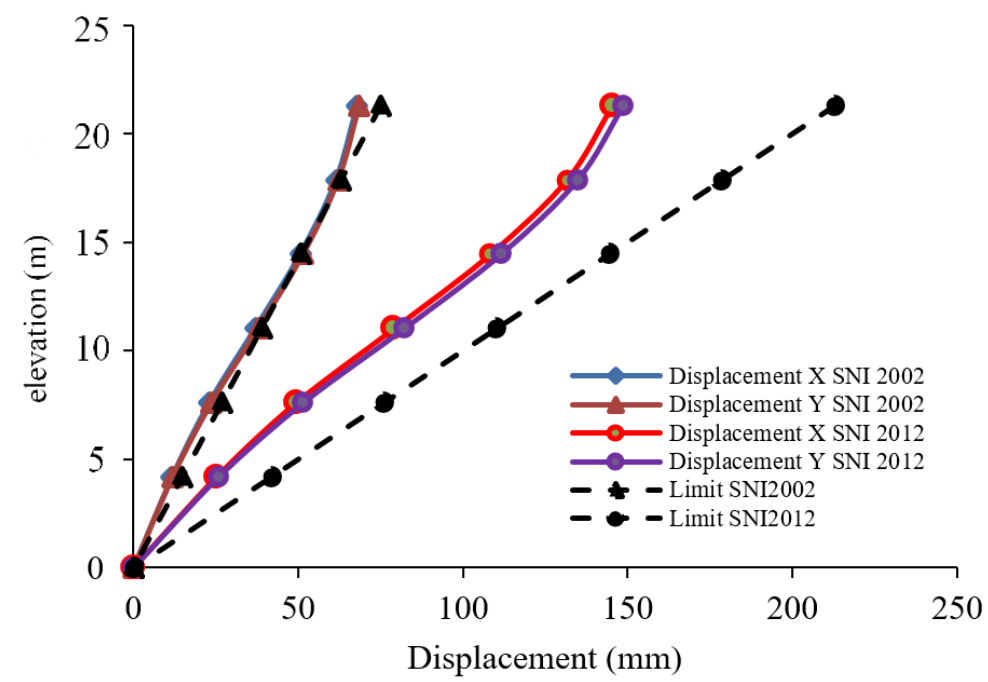

Fig. 7 - Comparison of the horizontal displacement using the response spectrum load based on SNI2002 and SNI2012

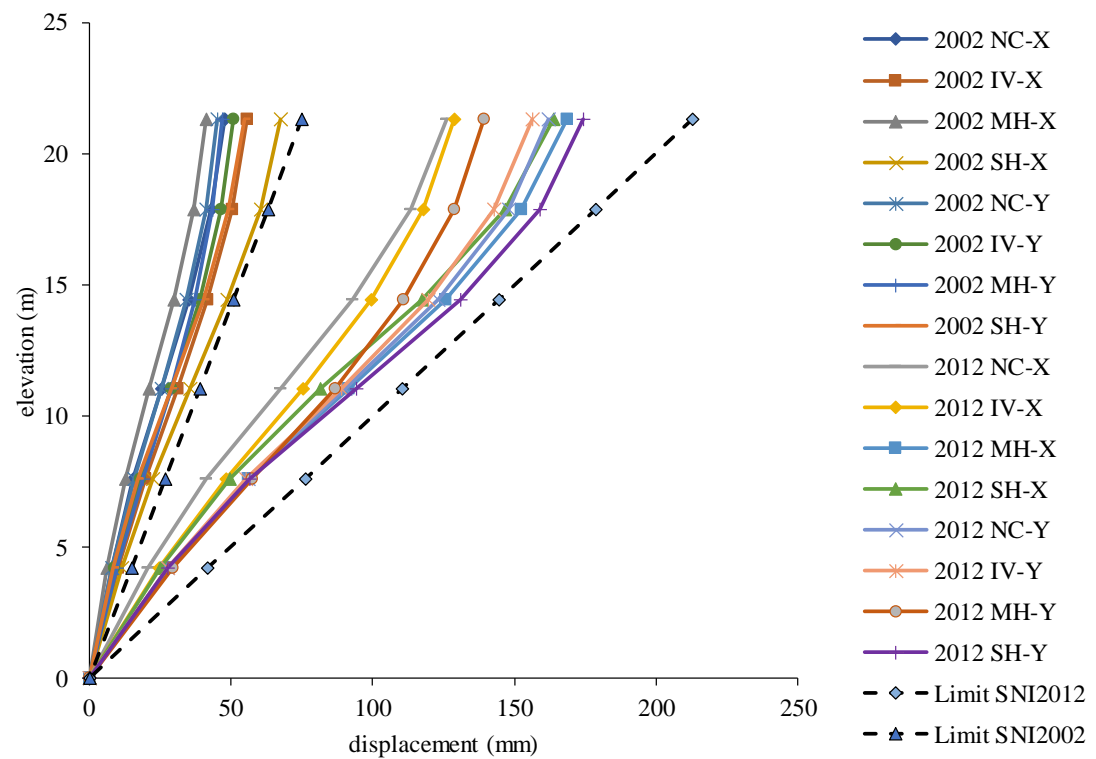

Fig. 8 - Comparison of horizontal displacement using time history load based on SNI2002 and SNI2012

The displacement checking either for the response spectrum or time history force in the previous discussion indicates that the building is still safe. A different pattern is shown when the observation took on each floor by analyzing the interstory drift. Fig. 9 shows the interstory drifts obtained from the simulation using the response spectrum for both SNI2002 and SNI2012, including their threshold. The threshold is set according to the interstory drift limit contained in each version of SNI. In SNI2002, it is mentioned that the allowable service limit should not exceed $0.03 / \mathrm{R}$ times the story height, where $\mathrm{R}$ is the reduction factor. While the threshold for SNI2012 is defined as shown in Table 1 based on the structure type and important factor of the building, it is taken as 1\%. According to ATC-40 [23], this building's performance level is specified as the Immediate Occupancy (IO). It shows that the interstory drifts in the $3^{\text {rd }}$ and $4^{\text {th }}$ floor exceeds the allowable limit for SNI2002 while in SNI2012 are not. This detected pattern does not appear in the total displacement interpretation; thus, interstory drift ratio can give better information to this vertically irregular building. 
The idea of interstory drift is by observing the relative lateral displacement rather than the cumulative displacement. Hence, the interstory drift ratio takes the individual displacement response of each category independently and compares it with the given threshold as regulated inside the codes. The total displacement depends on the displacement of the floor below. It also explains why the interstory drift thresholds are constant while the total displacement is not (Fig. 7 and Fig. 8). By observing Fig. 9, it also can be stated that the response spectrum analysis for SNI2002 is more conservative than SNI2012. This statement is agreed with the previous discussion for the total displacement.

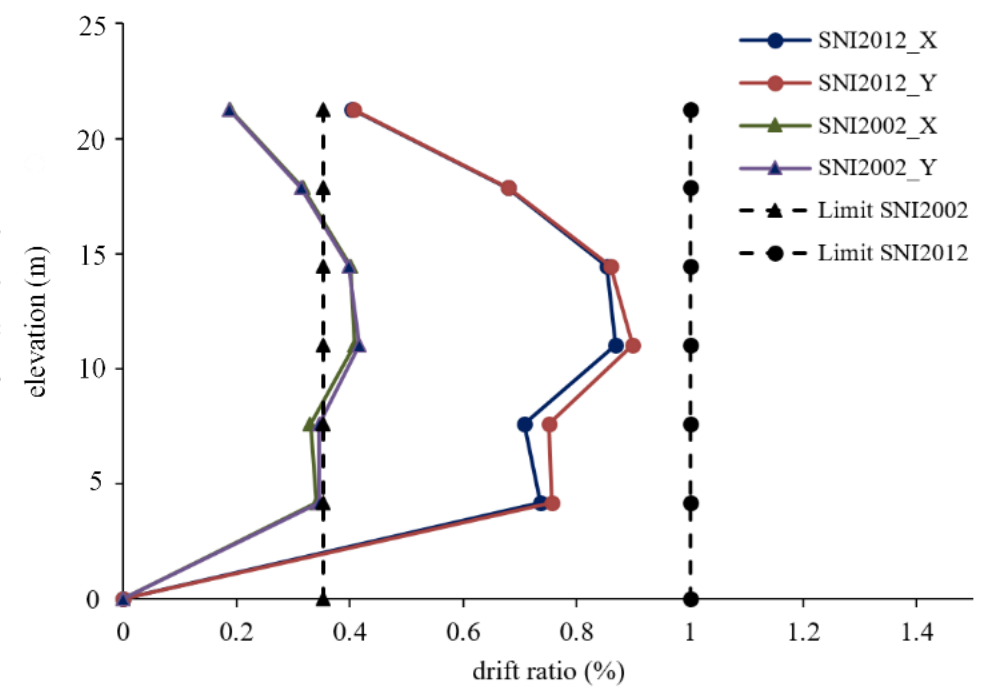

Fig. 9 - Comparison of interstory drift using response spectrum load based on SNI2002 and SNI2012

The interstory drift ratio obtained from the time history simulation is depicted in Fig. 10. Dissimilar to Fig. 9, the interstory drift in the time history analysis on the $3^{\text {rd }}$ and $4^{\text {th }}$ floor exceeds the limit for both SNI versions. The first reason for this is because, in the interstory drift ratio, the building response evaluation is performed independently by taking the ratio of relative displacement to its height. The limit is also not accumulated as used in the total displacement figure. The second may cause by the dynamical properties of exiting forces and the building. In time history analysis, the acceleration varies to the time, so the building responses are also influenced by the exiting force's frequency. In the response spectrum analysis, pseudo-acceleration applied on the building is determined by the building's natural period. As shown in Fig. 10, from all acceleration histories, the highest interstory drift is obtained from the SH, which is nearly 9\% larger than the limit for SNI2002 and about 10\% greater than the allowable limit SNI2012. These indicate that both versions of SNI for time history analysis provided a similar result in interstory drift performance.

It can also be obtained that the increase of interstory drift from SNI2002 to SNI2012 in the X and Y direction is 2.4 and 3.14. this difference is again influenced by the characteristic of the building and the exiting forces. Even the source of the earthquake is the same, but different axes have different characteristics. Besides, a significant surge of interstory drift appeared from the $2^{\text {nd }}$ to the $3^{\text {rd }}$ floor, which leads the interstory drifts to exceed its limits. This sudden change can be observed on both SNI2002 and SNI2012. All off exceedance limit are appeared in between the $2^{\text {nd }}$ to the $3^{\text {rd }}$ floor. This funding is agreed with those mentioned in previous research that the sudden change of stiffness causes a larger story drifts [13], i.e., this phenomenon caused by the building's setback. Structural members around the sudden change of geometry cause irregularity to generate greater deformation [12] and cause the building to be unsafe. Geometrical irregularities in this building automatically make the distribution of mass irregular and lead to the rise of its vulnerability to earthquake hazard areas. A weak point can occur when the sudden change of stiffness, mass, and strength in the building [4]. Therefore, it can be settled that there is potential damage located between the $2^{\text {nd }}$ and $3^{\text {rd }}$ floor.

To sum up, from all the above discussion, the total maximum displacement provides a good point for understanding the increase of building response by taking the top floor horizontal translation as the reference. However, this analysis is not enough for building with vertical irregularity because the building story level's weak point is not detected. Therefore, interstory drift ratio is strongly recommended for deeper analysis since its ability to encounter that deficiency. This building's interstory drift ratio proves that the weak point is located between the $2^{\text {nd }}$ and the $3^{\text {rd }}$ floor. 


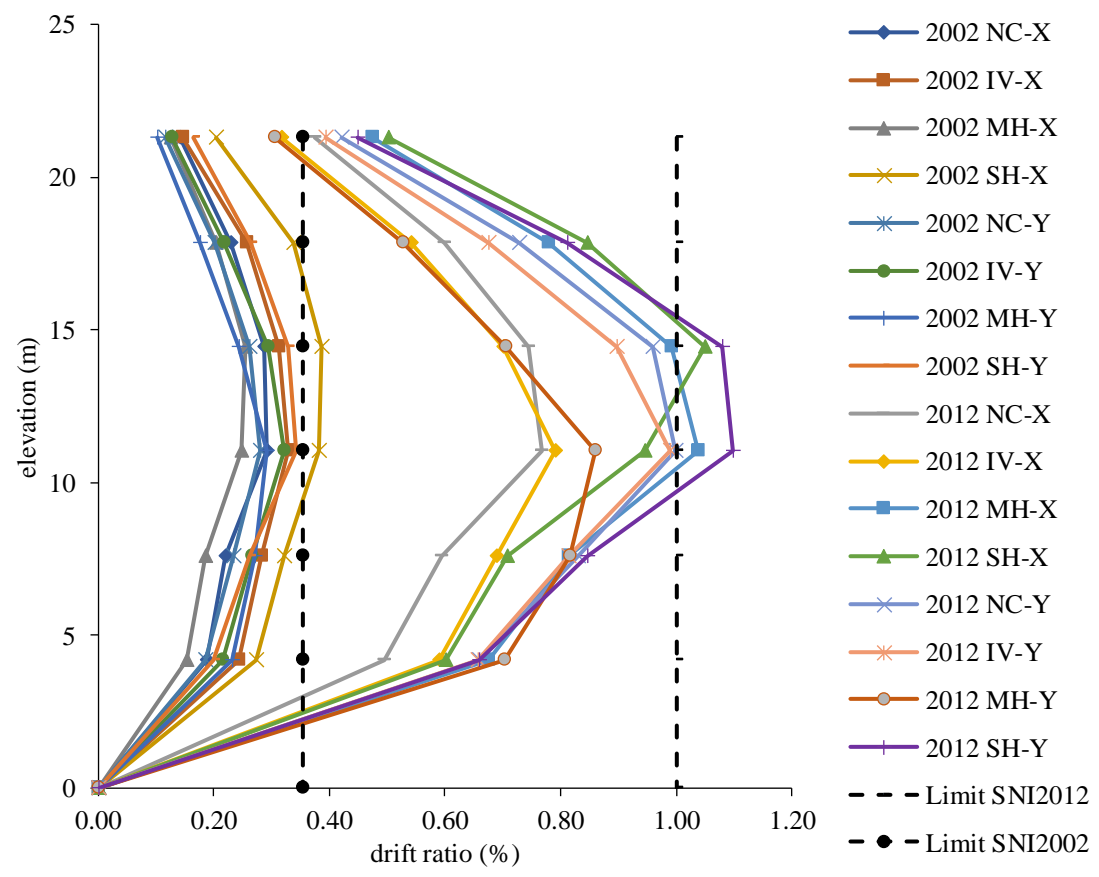

Fig. 10 - Comparison of interstory drift using time history in Building A based on SNI2002 and SNI2012

\section{Conclusions}

The presented research is an effort to provide a better understanding by giving a comparative study of Indonesian seismic code applied on the vertically irregular building. Response spectrum and time history analysis of four ground motions are applied according to the SNI2002 and SNI2012. The result shows that the average increase in base shear from SNI2002 to SNI2012 is nearly four times. From the simulation of building response through response spectrum analysis, it is found that the top floor displacement obtained from SNI2012 is about 2.2 times larger than SNI2002 while using time history analysis nearly three times greater.

The study gives valuable results for the vulnerable building with a setback. The use of interstory drift ratio to analyze the building with vertical irregularity is strongly suggested because it can provide a better interpretation for building response under the seismic loads. Moreover, it also has been proven that on the sudden change of stiffness and mass, the greater interstory drift occurs and leads to the potential damage on that area. In the presented case, the weak point is located between the $2^{\text {nd }}$ and $3^{\text {rd }}$ floor.

\section{Acknowledgment}

The authors would like to thank the Department of Civil Engineering, Universitas Muhammadiyah Yogyakarta, Kasihan, Bantul, Indonesia.

\section{References}

[1] Syamsi M. I. (2018). Respon model gedung beton bertulang dengan penambahan dinding pengisi terhadap beban gempa (Response of infilled wall RC building model under the earthquake loads). Semesta Teknika, 21, 33-42

[2] Haryanto Y. (2019). On the performance of a multi story irregular apartment building model under seismic load in Indonesian Moderately High Seismicity Region. Aceh International Journal of Science and Technology, 8, 1-11

[3] Athanassiadou C. J. (2008). Seismic performance of R/C plane frames irregular in elevation. Engineering Structures, 30, 1250-1261

[4] Sameer J. S. \& Shinde S. (2016). Seismic response of vertically irregular RC frame with mass irregularity. International Journal of Civil Engineering and Technology, 7, 257-264

[5] Mazza F. (2016). Nonlinear seismic analysis of rc framed buildings with setbacks retrofitted by damped braces. Engineering Structures, 126, 559-570

[6] SNI 03-1726-2002 (2002). Tata Cara Perencanaan Ketahanan Gempa untuk Bangunan Gedung (Earthquake Resistance Design Procedures for Buildings). Badan Standardisasi Nasional

[7] SNI 1726:2012 (2012). Tata Cara Perencanaan Ketahanan Gempa untuk Bangunan Gedung (Earthquake Resistance Design Procedures for Buildings). Badan Standardisasi Nasional 
[8] Arfiadi Y. \& Satyarno I. (2013). Perbandingan spektra desain beberapa kota besar di Indonesia dalam SNI Gempa 2012 dan SNI Gempa 2002 (233S) (Comparison of design spectra of big cities in Indonesia between SNI 2012 and SNI 2002 (233S)). Konferensi Nasional Teknik Sipil, Surakarta

[9] Soni D. P. \& Mistry B. B. (2006). Qualitative review of seismic response of vertically irregular building frames. Journal of Earthquake Technology, 43, 121-132

[10] Mwafy A. \& Khalifa S. (2017). Effect of vertical structural irregularity on seismic design of tall buildings. The Structural Design of Tall and Special Buildings, 26, e1399

[11] Shahrooz B. M. \& Moehle J. P. (1990). Seismic response and design of setback buildings. Journal of Structural Engineering, 116, 1423-1439

[12] Dutta S. C., Das P. K. \& Sengupta P. (2017). Seismic behaviour of irregular structures. Structural Engineering International, 27, 526-545

[13] Le- Trung K. (2012). Evaluation of seismic behaviour of steel special moment frame buildings with vertical irregularities. The Structural Design of Tall and Special Buildings, 21, 215-232

[14] Soni D. P. \& Mistry B. B. (2006). Qualitative review of seismic response of vertically irregular building frames. ISET Journal of Earthquake Technology, Technical Note, 43, 121-132

[15] Humar J. \& Wright E. (1977). Earthquake response of steel- framed multistorey buildings with set- backs. Earthquake Engineering and Structural Dynamics, 5, 15-39

[16] Muljati I. \& Lumantarna B. (2011). Seismic Performance of Structures with Vertical Geometric Irregularity Designed Using Partial Capacity Design. PhD Thesis, Petra Christian University

[17] Aslani H. \& Miranda E. (2005). Probabilistic Earthquake Loss Estimation and Loss Disaggregation in Buildings. Report No. 157, Stanford University

[18] FEMA (2012). FEMA P58-1: Seismic Performance Assessment of Buildings. Volume 1-Methodology. Federal Emergency Management Agency

[19] ASCE (2014). Seismic Evaluation and Retrofit of Existing Buildings (ASCE/SEI 41-13). American Society of Civil Engineers

[20] CEN (2004). European Standard ENV 1998-1-1/2/3. Eurocode 8: Design Provisions for Earthquake Resistance of Structures - Part I: General Rules. Comite Europeen de Normalisation

[21] FEMA (2006). FEMA 451: NEHRP Recommended Provisions: Design Examples. Federal Emergency Management Agency.

[22] Sutrisno, Putra R. R. \& Ganefri (2017). A comparative study on structure in building using different partition receiving expense earthquake. International Journal of Geomate, 13, 34-39

[23] ATC-40 (1996). Seismic Evaluation and Retrofit of Concrete Buildings. Applied Technology Council 